\title{
Vitamin D—update for the pediatric rheumatologists
}

\author{
Jelena Vojinovic ${ }^{1^{*}}$ and Rolando Cimaz $^{2+}$
}

\begin{abstract}
Vitamin D, upon its discovery one century ago, was classified as a vitamin. This classification still greatly affects our perception about its biological role. 1,25(OH)2D (now known as the D hormone) is a pleiotropic steroid hormone that has multiple biologic effects. It is integral to the regulation of calcium homeostasis and bone turnover as well as having anti-proliferative, pro-differentiation, anti-bacterial, immunomodulatory and anti-inflammatory properties within the body in various cells and tissues. Vitamin D (cholecalciferol) should be considered a nutritional substrate that must be ingested or synthesized in sufficient amounts for the further synthesis of the very important regulatory steroid hormone ( $\mathrm{D}$ hormone), especially in patients with pediatric rheumatic diseases (PRD).

Vitamin D insufficiency or deficiency was shown to be pandemic and associated with numerous chronic inflammatory and malignant diseases and even with increased risk of mortality. Several studies have demonstrated that a high percentage of children with pediatric rheumatic diseases (PRD-e.g., JIA, jSLE) have a vitamin D deficiency or insufficiency which might correlate with disease outcome and flares. Glucocorticoids used to treat disease may have a regulatory effect on vitamin D metabolism which can additionally aggravate bone turnover in PRD. An effort to define the optimal serum 25(OH)D concentrations for healthy children and adults was launched in 2010 but as of now there are no guidelines about supplementation in PRD.

In this review we have tried to summarize the strong evidence now suggesting that as the knowledge of the optimal approach to diagnosis and treatment PRD has evolved, there is also an emerging need for vitamin D supplementation as an adjunct to regular disease treatment. So in accordance with new vitamin D recommendations, we recommend that a child with rheumatic disease, especially if treated with steroids, needs at least 2-3 time higher doses of vitamin D than the dose recommended for age (approximately $2000 \mathrm{UI} /$ day). Vitamin D supplementation has become an appealing and important adjunct treatment option in PRD.
\end{abstract}

Keywords: Vitamin D recommendations, Juvenile idiopathic arthritis, Juvenile systemic lupus erythematosus, D hormone, Pediatric rheumatic diseases

\section{Background}

One century after its discovery and three Nobel prizes awarded for discoveries in this topic [1], we have clear evidences that the so-called vitamin $\mathrm{D}$ is in fact a pleiotropic steroid hormone similar to other steroid hormones. Unfortunately, its primary classification into the vitamins still deeply influences our professional perception about $1,25(\mathrm{OH}) 2 \mathrm{D}$ biological function and impact on the occurrence and outcome of the some rheumatic diseases [4]. It

\footnotetext{
* Correspondence: vojinovic.jelena@gmail.com

${ }^{\dagger}$ Equal contributors

${ }^{1}$ Clinic of Pediatrics, Clinical Center, Faculty of Medicine, University of Nis, Bul dr Zorana Djindjica 48, 18000 Nis, Serbia

Full list of author information is available at the end of the article
}

is necessary to distinguish cholecaliferol (commonly called vitamin D), a nutritional precursor compound, from the $1,25(\mathrm{OH}) 2 \mathrm{D}$-vitamin D hormonal form. This hormonal form is synthetized after a complex, endocrine-regulated biochemical process. This $1,25(\mathrm{OH}) 2 \mathrm{D}$ D hormone has its own endocrine, paracrine and autocrine control [5]. As hormone is defined as a chemical substance produced in one part of the body that stimulates functional activity in another part [6], it is clear that what we call vitamin D does not fulfill the vitamin definition criteria but rather those for a hormone. We will discuss the biologic roles of vitamin $\mathrm{D}$ in this review as that of the D hormone.

When prescribing medication for the treatment of rheumatic diseases, most of pediatric rheumatologists do not recommend vitamins as mandatory, including 
vitamin D. Yet newer scientific studies may soon change that approach. Beside regulation of calcium homeostasis and bone turnover, the $\mathrm{D}$ hormone has proven antiproliferative, pro-differentiation, anti-bacterial, immunomodulatory and anti-inflammatory properties within the body in various cells and tissues [2,3]. This effects can be achieved only if the D hormone $(1,25(\mathrm{OH}) 2 \mathrm{D})$ itself, or its agonist, is bound to vitamin $\mathrm{D}$ receptor (VDR). The discovery that vitamin $\mathrm{D}$ receptor agonists possess immunomodulatory and anti-tumor properties prompted research to investigate the possibility that these agonists might be used as a therapeutic agent for different autoimmune and malignant diseases $[7,8]$.

\section{Review}

Randomized controlled trials providing recommendations for vitamin D supplementation in pediatric patients with PRD are lacking. Yet several recent studies have supported the importance of and necessity for vitamin D supplementation within standard treatment protocols and guidelines of rheumatic diseases in childhood. A study of Arkema et al. [9] investigated the association between UV-B light exposure and the risk of developing rheumatoid arthritis (RA) among women enrolled in two large prospective cohort studies [the Nurses' Health Study (NHS) and the NHSII]. These studies confirmed a significantly decreased risk of RA with higher UV-B exposure especially between birth and age 15 years. Nisar et al. [10] published a systemic literature review and meta-analysis of current evidence on vitamin D in JIA, summarizing data from 19 papers that were largely supporting positive benefits. Robinson et al. [11] presented data from Atherosclerosis Prevention in Pediatric Lupus Erythematosus (APPLE) trial and found vitamin D deficiency to be common in pediatric lupus and independently associated with elevated hsCRP and an increased cardiovascular disease risk. Finally, Holick reviewed recent recommendations and clinical guidelines [12] and suggested that vitamin D supplementation of up to $2000 \mathrm{IU} / \mathrm{d}$ appears to be safe and well tolerated in children with chronic diseases.

\section{D-hormone synthesis}

Cholecalciferol is pre-hormonal form of D hormone that must be ingested or generated in the skin where one of the rings of the precursor molecule (7-dehydrocholesterol) is broken down by ultraviolet B-light (UV-B, sun light). In part this explains why, when discovered a century ago, it was classified as vitamin. Actually, as previously noted, this substance is a member of a group of steroid molecules (secosteroids) with a common A, B, $\mathrm{C}$ and $\mathrm{D}$ ring structure derived from the cyclo-pentano-perhydrophenanthrene ring structure, very similar to cholesterol [13].

After the UV-B activity, this compound undergoes a very complex metabolic process that is controlled by classic endocrine feed-back mechanisms and becomes a biologically active hormone. It must be first hydroxylated in the liver, at the carbon 25-position by 25-hydroxylase, to form $25(\mathrm{OH}) \mathrm{D}$, known as a calcidiol or calcifediol. Several cytochrome P450 (CYP) isoforms (including the mitochondrial CYP27A1 and the microsomal CYP2R1, CYP3A4 and CYP2J3) accomplish this hydroxylation step. CYP2R1 is thought to be the high-affinity 25 -hydroxylase [14]. The $25(\mathrm{OH}) \mathrm{D}$ form is the most plentiful and stable prehormonal metabolite of vitamin $\mathrm{D}$ in human serum with a high affinity to bind serum vitamin $\mathrm{D}$ binding protein (VDBP) and other albumin superfamily proteins in the blood. As such, the 25(OH)D level in the serum is the best indicator of vitamin $\mathrm{D}$ entering the host, either by cutaneous synthesis or by ingestion in the diet. Nevertheless, this $25(\mathrm{OH}) \mathrm{D}$ form is still not a hormone, rather a pre-hormonal form of the natural hormone, and does not exert any biological activity in the body [15].

Calcidiol $(25(\mathrm{OH}) \mathrm{D})$ is then transported through the bloodstream, bound to vitamin $\mathrm{D}$ binding protein (VDBP), to the proximal tubule of the kidney, where it is hydroxylated at the $1 \alpha$-position to form the final biologically active form of $\mathrm{D}$ hormone named calcitriol $(1 \alpha, 25(\mathrm{OH}) 2 \mathrm{D})$, by the enzyme 25 -hydroxyvitamin $\mathrm{D}$ $1 \alpha$-hydroxylase (CYP27B1) [16]. Activity of this enzyme is increased by parathyroid hormone $(\mathrm{PTH})$ secreted by the parathyroid gland, which is the pivotal activator of CYP27B1 in proximal tubule cells and decreases with aging [17]. Thereafter, the synthesized calcitriol becomes the real D hormone with full biological activity similar to other steroid hormones. The D hormone increases intestinal calcium absorption and mobilizes calcium from the skeleton while calcium level in blood regulates PTH secretion and CYP27B1 activity. These activities are clear examples of endocrine regulation due to D hormone production.

\section{D hormone biological activity}

For many years it was believed that regulation of calcium homeostasis within the body with a positive influence on bone turnover were the only crucial roles of this hormone. These roles were why it was considered to be a vitamin critical for bone health. This tenet remains correct, but it is now understood that all monocytemacrophage derived cells, including those present in many tissues and various epithelia, are able to express $1 \alpha$-hydroxylase and to synthesize calcitriol locally, if there is a availability of the $25(\mathrm{OH}) \mathrm{D}$ substrate [18]. Synthetized D hormone can act on cells and in the tissues in an autocrine or paracrine manner, and the synthesized D-hormone (calcitriol) serves as connection between extracellular stimuli and genomic response of the cells [19].

It is recognized that $1 \alpha, 25(\mathrm{OH}) 2 \mathrm{D}$ has high affinity to bind vitamin $\mathrm{D}$ receptor (VDR) due to the presence of an $\mathrm{OH}$ group at the $1 \alpha$ position. The VDR gene shows 
its highest expression in tissues with high metabolic activity, such as kidneys, bone and gut, but has low to moderate expression in nearly all other human tissues. VDR, when bound to hormone, heterodimerizes with the retinoic acid-X-receptor (RXR) and this complex binds to the vitamin $\mathrm{D}$ responsive element (VDRE) acting as a transcriptional factor to enhance or repress gene transcription [20].

It has been estimated that at least 200 tissues and as many as 2000 genes are directly or indirectly controlled by this transcriptional complex [21]. Only high doses of D hormone can induce genetic effects including immunomodulatory actions [20] while physiological actions have to be mediated via the genetic and epigenetic regulatory actions of the VDR transcriptional complex [22]. VDR protein has been detected both in the cytosol (associated with sarcoplasmic reticulum $\mathrm{Ca} 2+-$ ATPase) and in plasma membranes. This ubiquitous presence of the VDR protein may explain some of the rapid non-genomic actions of $1 \alpha, 25(\mathrm{OH}) 2 \mathrm{D}$ such as calcium up-take that are related to calcium homeostasis and bone mineralization [23].

The signaling pathways of all steroid hormones (glucocorticoid, sex hormones) occur through cellular and nuclear hormone receptors [25]. All of these hormones influence bone formation and immune regulation. Steroid nuclear receptors, when bound to their agonist hormone, under control of co-regulators, catalyze or mediate chromatin remodeling, epigenetic modification, receptor recycling, and ultimately gene expression [26]. Gene regulation appears to be modulated by dual modifications of histone acetylation and DNA methylation. The $1 \alpha, 25(\mathrm{OH}) 2 \mathrm{D}$ hormone has been shown to be a potent genetic and epigenetic regulator. This could be explanation for the possible pathogenetic role of low vitamin $\mathrm{D}$ status in immune-mediated diseases $[24,25]$.

Using the same signaling pattern, $1,25(\mathrm{OH}) 2 \mathrm{D}$, locally produced in the tissues, exerts its effects on several immune cells, including macrophages, dendritic cells (DCs), $\mathrm{T}$ and $\mathrm{B}$ cells.

Macrophages and DCs constitutively express vitamin $\mathrm{D}$ receptor (VDR), whereas VDR expression in T cells is up-regulated after activation [27]. In macrophages and monocytes, 1,25(OH)2D positively influences its own effects by increasing the expression of VDR and the cytochrome P450 protein CYP27B1 (autocrine regulation). Toll-like-receptor (TLR)-mediated signals can also increase the expression of VDR.

The 1,25(OH)2D hormone also induces monocyte proliferation and production of interleukin-1 (IL-1) and cathelicidin (an antimicrobial peptide) by macrophages, thereby contributing to innate immune response [28, 29]. The 1,25(OH)2D hormone decreases DC maturation, inhibiting up- regulation of the expression of MHC class
II, CD40, CD80 and CD86. In addition, it decreases IL-12 production of DCs and induce production of IL- 10 .

In T cells, 1,25(OH)2D decreases the production of IL2 , IL-17 and interferon- $\gamma($ IFN $\gamma)$ and attenuates the cytotoxic activity and proliferation of CD4+ and CD8+ T cells [30]. The 1,25(OH)2D hormone might also promote the development of forkhead box protein 3 (FOXP3) + regulatory T (TReg) cells and IL-10-producing T regulatory type 1 (TR1) cells [31,32]. Finally, 1,25(OH)2D blocks B cell proliferation, plasma-cell differentiation and immunoglobulin production [33].

It is clear that the D hormone exerts its effects on many crucially important immunoregulatory proteins and cells [34]. Some of them are recognized as possible causative immune factors for the development of PRDs. Due to the D hormone's proven capability to induce tolerogenic immune response, improve impaired $\mathrm{T}$ and $\mathrm{B}$ cell function, and enhance innate immunity response, a deficiency or insufficiency of D hormone may well have causative or risk factor effects [35] in pediatric rheumatic diseases.

\section{D hormone and pediatric rheumatic diseases}

Numerous studies suggest that the 1,25(OH)2D hormone appears to play important roles in the pathogenesis of several autoimmune diseases, such as diabetes type I, multiple sclerosis and rheumatoid arthritis. Vitamin D deficiency has been found as a potential risk factor for increased cardiovascular risk, abnormal HDL and LDL cholesterol levels, hypertension, hyperglycemia, diabetes [36-41]. As this hormone affects bone and the immune system in many profound ways, pediatric rheumatologists cannot ignore its potential roles in PRDs.

\section{a) Bone health in children}

Children and adolescents need to achieve peak bone mass by age 18 years or enter adulthood with suboptimal bone mass and risk of osteoporosis as adults [42]. The inflammatory nature of PRDs may reduce the ability to achieve peak bone mass [43] due to the inflammation, pain, decreased activity, and other factors. The necessity to use glucocorticoids for the treatment of pediatric rheumatic diseases is an additional risk factor for bone mass loss during childhood and adolescence [44]. It has been shown that patients with JIA and jSLE and other chronic inflammatory diseases have an increased fracture risk [45]. Glucocorticoids may have a regulatory effect on vitamin D metabolism which, in the presence of low vitamin D levels, may additionally negatively affect bone turnover [46].

The US Centers for Disease Control and Prevention (CDC) reported in 2006 that healthy children in the US are vitamin D deficient in approximately $9-11 \%$ at age 
1-8 years, $19-22 \%$ at age $9-13$ years and $22 \%$ at age 14-18 years [47]. The possible significance of vitamin $\mathrm{D}$ deficiency in JIA was noted more than 20 years ago $[48,49]$. Recently Pelajo et al. [50] reported that $20 \%$ of all children attending clinic were vitamin $\mathrm{D}$ deficient while children with autoimmune disorders had a 2-3 fold greater probability of being vitamin $\mathrm{D}$ deficient compared to children with non-autoimmune conditions. Soybilgic et al. [51] assessed practices of North American pediatric rheumatologists regarding monitoring, prevention, and treatment of low bone mineral density (BMD) in children on long-term glucocorticoid treatment and found that $79 \%$ "rarely" or "never" obtained a baseline BMD measurement prior to initiation of glucocorticoid therapy. Yet despite the lack of BMD assessment, 93 \% "frequently" or "always" prescribed calcium for patients on long-term corticosteroid therapy, $81 \%$ "frequently" or "always" prescribed vitamin D, and $40 \%$ of the survey responders prescribed combined calcium/vitamin tablets.

It is very important to note that there are no data about vitamin $\mathrm{D}$ formulation and doses used routinely by pediatric rheumatologists. This may be partly due to the fact that there are no clear recommendations concerning this issue for pediatric rheumatic diseases. In adults, the Endocrine Society has recommended two to three time higher doses of vitamin D supplementation for adults treated with glucocorticoids than for the healthy population [52].

\section{b) Juvenile Idiopathic Arthritis (JIA)}

Interest and knowledge about vitamin D in JIA has increased in last decade and deficiency or insufficiency has been considered as important environmental determinant of the disease [53]. As mentioned, several studies have shown that vitamin $\mathrm{D}$ deficiency is associated with rheumatoid arthritis (RA) and type 1 diabetes (T1D) and that supplementation may be inversely associated with the disease onset $[9,54,55]$. Unfortunately these types of studies are missing for JIA and other pediatric rheumatic diseases. Recent meta-analysis performed by Nisar et al. [10] included 19 papers reporting values of $25(\mathrm{OH}) \mathrm{D}$ and $1,25(\mathrm{OH}) \mathrm{D}$ (14 and 11 , respectively) in JIA, using similar assays, but could not find evidence to link vitamin D deficiency with JIA due to the lack of agreed definition of vitamin $\mathrm{D}$ deficiency in pediatric population. The main biases of this meta-analysis were that it did not use cut-off definitions for insufficiency and deficiency and the heterogeneity of study designs included in the meta-analysis. Nevertheless it is an important and useful overview and provides further evidence of the relatively high prevalence of vitamin D deficiency in JIA, especially in the systemic and polyarticular
JIA catagories in which children are often treated with steroids. Mean levels of $25(\mathrm{OH}) \mathrm{D}$ within groups studied were $24.56 \mathrm{ng} / \mathrm{ml}$ (range, 11.5-56.4 ng/ml). These results are in agreement with a recent study of Pelajo et al. [56] who have found vitamin D deficiency $(\leq 19 \mathrm{ng} / \mathrm{ml})$ in $13 \%$ and insufficiency $(20-29 \mathrm{ng} / \mathrm{ml})$ in $42 \%$ of JIA patients, including those who were supplemented. The same authors could not find any association of $25(\mathrm{OH}) \mathrm{D}$ levels with disease activity (measured with JADAS-27), except in a subgroup of new-onset JIA who had non-significant negative correlation. Additional data about 25(OH)D levels and the influence on disease activity have been provided by a recent publication of Stagi $\mathrm{S}$ et al. [57]. These authors have confirmed significantly reduced $25(\mathrm{OH}) \mathrm{D}$ levels in JIA patients. In their study patients with active disease and/or frequent relapses have had significantly reduced $25(\mathrm{OH}) \mathrm{D}$ levels compared to patients with no active disease or infrequent flares. Two other studies $[58,59]$ have found that the percent true calcium absorption is below normal in children with JIA, while vitamin D supplementation (2000 IU) did appear to increase serum $25(\mathrm{OH}) \mathrm{D}$ and normalize serum calcium levels even without calcium supplementation.

\section{c) Juvenile Systemic Lupus Erythematosus (jSLE) and Dermatomyositis (JDM)}

High prevalence of vitamin D deficiency was shown in adult SLE but recent studies [60, 61] demonstrated that, despite vitamin $\mathrm{D}$ supplementation, deficiency is present in juvenile SLE.

Furthermore, vitamin D deficiency strongly correlated with SLEDAI, C4 level and BMD (low spine and whole body) [60]. Stagi et al. [61] has shown that jSLE patients exhibit lower 25(OH)D levels than controls with the lower values observed in patients with active vs. inactive disease.

Urinary losses of $25(\mathrm{OH}) \mathrm{D}$ and vitamin $\mathrm{D}$ binding protein (DBP) could be a reason for the low vitamin D status in pediatric lupus patients [62]. Robinson et al. reported vitamin $\mathrm{D}$ deficiency in jSLE patients, an inverse relationship between $25(\mathrm{OH}) \mathrm{D}$ levels and proteinuria, and an association with proliferative glomerulonephritis in patients with jSLE [63]. The same group published very interesting data as results of the APPLE study (Atherosclerosis Prevention in Pediatric Lupus Erythematosus) [64]. Briefly, the study confirmed that vitamin D deficiency is common in jSLE and independently associated with elevated hsCRP [11].

Additionally, jSLE patients with serum 25(OH)D $\geq$ $20 \mathrm{ng} / \mathrm{mL}$ had less mean-max CIMT (carotid intima medial thickness) progression following 3 years of atorvastatin treatment that could suggest that vitamin D deficiency may contribute to heightened inflammation and cardiovascular risk [65]. 
Data about vitamin D levels in JDM is very limited. Two studies, both including a small number of patients, observed that $25(\mathrm{OH}) \mathrm{D}$ level to be lower among children with high disease activity compared to low disease activity JDM patients $[48,63]$. One recent study confirmed a significant association of low 25(OH)D serum levels with idiopathic inflammatory myopathies, including JDM [66].

It is very interesting to point out that association of vitamin $\mathrm{D}$ deficiency with pediatric rheumatic diseases may not be the only biologically important $\mathrm{D}$ hormone pathway. Polymorphism of genes regulating D hormone synthesis may be connected with the presence or severity of many rheumatic diseases [67]. Polymorphisms in vitamin $\mathrm{D}$ pathway related genes has been found to be associated with increased likelihood of being vitamin D deficient [68]. Ellis et al. [69] recently published data about impressive evidence of gene epistasis among all genes (GC, VDR, CYP24A1, CYP2R1, and DHCR7) regulating $\mathrm{D}$ hormone synthesis as well as the PTPN2 gene which is a vitamin $\mathrm{D}$ responsive gene determining susceptibility to JIA and type 1 diabetes. Several studies indicated a possible association of VDR receptor gene polymorphism with RA and JIA [70, 71]. In our study, we have found that presence of $f$ variant of FokI VDR polymorphism was associated with a worse outcome and a longer need for biologic treatment in JIA patients [70].

\section{Optimal D hormone levels}

The best method to determine a person's vitamin D status is to measure the circulating level of $25(\mathrm{OH}) \mathrm{D}$. Serum levels of $1 \alpha, 25(\mathrm{OH}) 2 \mathrm{D}$ are often normal or even elevated in both children and adults who are vitamin $\mathrm{D}$ deficient due to its very short half-life and tight physiological control by PTH which can increase renal production of calcitriol (by stimulating $1 \alpha$-hydroxylase activity). The vitamin D hormonal form is synthetized and accumulated to a large degree in the tissues but there it cannot be measured [15].

For a long time there has been no consensus on the optimal concentrations of serum 25(OH)D. Most authors have used the cut-off values of $10-15 \mathrm{ng} / \mathrm{mL}$ to define vitamin D deficiency. In 2010 the Institute of Medicine (IOM) concluded that vitamin $\mathrm{D}$ deficiency should be defined as a $25(\mathrm{OH}) \mathrm{D}$ level of $<20 \mathrm{ng} / \mathrm{mL}$ for children and adults [72]. Based on a study in postmenopausal women in whom a rise of $25(\mathrm{OH}) \mathrm{D}$ level from $\sim 20 \mathrm{ng} / \mathrm{mL}$ to $\sim 32 \mathrm{ng} / \mathrm{mL}$ increased their efficiency of intestinal calcium absorption by $65 \%$, the Endocrine Clinical Practice Guidelines Committee of the Endocrine Society proposed a new definition of vitamin D insufficiency and sufficiency [52]. Vitamin D deficiency is now defined as $25(\mathrm{OH}) \mathrm{D}<20 \mathrm{ng} / \mathrm{mL}$, vitamin D insufficiency as 21$29 \mathrm{ng} / \mathrm{mL}$, and vitamin D sufficiency as $>30 \mathrm{ng} / \mathrm{mL}$ for both children and adults. It is suggested that maintenance of a $25(\mathrm{OH}) \mathrm{D}$ level between 40 and $60 \mathrm{ng} / \mathrm{mL}$ is ideal and up to $100 \mathrm{ng} / \mathrm{mL}$ is safe [73]. These recommendations are summarized in Table 1. In adults it was shown that supplementation of 1000 IU of cholecalciferol per day increases $25(\mathrm{OH}) \mathrm{D}$ level by $7-10 \mathrm{ng} / \mathrm{ml}$ and it is believed that $100 \mathrm{IU}$ can increase $25(\mathrm{OH}) \mathrm{D}$ level by as much as $2-3 \mathrm{ng} / \mathrm{ml}$ when serum $25(\mathrm{OH}) \mathrm{D}$ is below $15 \mathrm{ng} / \mathrm{ml}$ [74].

As IOM recommendations are designed for healthy individuals of all ages, their direct application in children with JIA or other rheumatic diseases could be challenging especially due to long term steroid usage and high

Table 1 Recommendations for patents at risk for D deficiency (JIA and other rheumatic inflammatory diseases)

\begin{tabular}{|c|c|c|c|c|c|c|}
\hline \multirow[t]{2}{*}{ Age } & \multicolumn{3}{|c|}{ IOM recommendations for healthy children } & \multicolumn{2}{|c|}{$\begin{array}{l}\text { IOM recommendations for healthy } \\
\text { children at risk of vitamin D deficiency }\end{array}$} & \multirow{2}{*}{$\begin{array}{l}\text { Proposed recommendation for } \\
\text { children with rheumatic diseases } \\
\text { IU/day }\end{array}$} \\
\hline & EAR IU $(\mu \mathrm{g}) /$ day & RDA IU $(\mu \mathrm{g}) /$ day & UL IU $(\mu \mathrm{g}) / \mathrm{day}$ & Daily requirement IU/day & UL, IU/day & \\
\hline \multicolumn{7}{|l|}{ Infants } \\
\hline $0-6$ months & $400(10)$ & & $1000(25)$ & $400-1000$ & 2000 & 1000 \\
\hline $6-12$ months & $400(10)$ & & $1500(38)$ & $400-1000$ & 2000 & $1500-2000$ \\
\hline \multicolumn{7}{|l|}{ Children } \\
\hline $1-3$ years & $400(10)$ & $600(15)$ & $2500(63)$ & $600-1000$ & 4000 & 2000 \\
\hline $4-8$ years & $400(10)$ & $600(15)$ & $3000(75)$ & $600-1000$ & 4000 & 2000 \\
\hline \multicolumn{7}{|l|}{ Boys } \\
\hline 9-13 years & $400(10)$ & $600(15)$ & $4000(100)$ & $600-1000$ & 4000 & 2000 \\
\hline $14-18$ years & $400(10)$ & $600(15)$ & $4000(100)$ & $600-1000$ & 4000 & 2000 \\
\hline \multicolumn{7}{|l|}{ Girls } \\
\hline $9-13$ years & $400(10)$ & $600(15)$ & $4000(100)$ & $400-2000$ & 4000 & $2000-3000$ \\
\hline $14-18$ years & $400(10)$ & $600(15)$ & $4000(100)$ & $400-2000$ & 4000 & $2000-3000$ \\
\hline
\end{tabular}

Adapted from references 52 and 72; EAR-estimated average requirement; RDA-recommended daily allowance; UL-tolerable upper intake level 
disease activity. These adverse effects seen in JIA and other rheumatic diseases argue for higher supplementation doses in these children [52]. It is of great importance for physicians to understand that measured $25(\mathrm{OH}) \mathrm{D}$ level is a reflection of food and/or supplement intake, but at the same time it can be a result of increased utilization and need for this pre-hormonal substrate in the local tissues (especially immune cells and bone) in the state of chronic inflammation (Fig. 1). That is why, for children with rheumatic diseases, we recommend pediatric rheumatologists to use at least doubled daily allowance doses (RDA) of cholecalciferol as vitamin D supplementation, especially for patients treated with glucocorticoids (Table 1).

As discussed earlier, supplementation with vitamin D (cholecalciferol) is unfortunately not common in everyday pediatric rheumatology practice [51]. Additionally there is huge variety of formulations (ergocalciferol or cholecalciferol, with or without calcium) used in multiple different dosing regimens. Cholecalciferol (D3) should be the preferred form for supplementation as it was shown that it can yield greater increases in $25(\mathrm{OH}) \mathrm{D}$ compared to an equivalent dose of ergocalferol (D2). Additionally, 25(OH)D is the required substrate for conversion to1,25(OH)2D at the cellular level and D2 (ergocalciferol) does not have the long-term potency as D3 [75]. Supplementation with calcitriol $(1,25(\mathrm{OH}) 2 \mathrm{D}$ - final hormonal form) or other vitamin $\mathrm{D}$ analogues is generally recommended only for children with chronic kidney disease, patients taking anticonvulsants or suffering from malabsorption syndromes. The patients are usually unable to metabolize cholecalciferol to the hormonal form [76].

Among pediatric rheumatologists, there may be fear that using higher vitamin D doses could carry a risk of hypercalcemia and toxicity. We doubt this concern is justified since infants who received the huge doses of $200,000-600,000$ IU of vitamin D2 or vitamin D3 orally for vitamin $\mathrm{D}$ deficiency have had no reports of toxicity. Rather neonates treated with 2000 IU of vitamin D3 during the first year of life appeared to have a reduced risk of developing an autoimmune disease, ie type 1 diabetes, and did not experience toxicity [54]. Also, the risk of hypercalcemia can be lowered if additional calcium intake is avoided since it has been shown

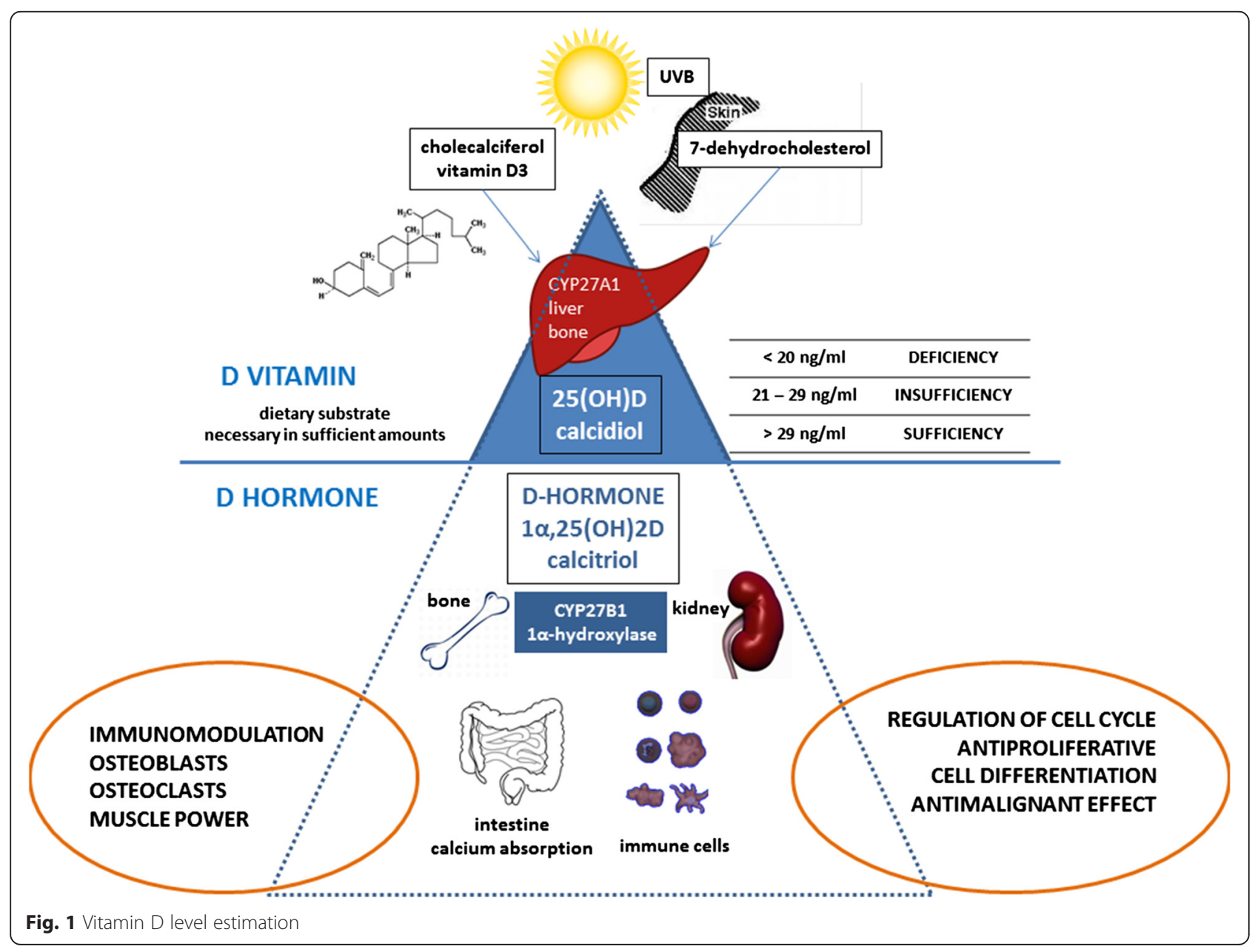


that calcium has limited potential to effect bone acquisition [59].

D hormone as a natural compound is necessary to be present in high concentrations in cells and tissues to achieve genetic and epigenetic effects. This is why pharmaceutical companies focused on the development of more than $3000 \mathrm{D}$ hormone analogs (agonists) [8]. There is some evidence that vitamin D analogs can even overcome steroid resistance [77] and improve disease outcome [78] but randomized controlled trials and other studies are needed.

\section{Conclusion}

Vitamin D deficiency has clearly been recognized as pandemic and connected with numerous non-infectious diseases with increased incidence in the modern age (cardiovascular, malignant, autoimmune, cognitive etc.) and even increased risk of mortality [74, 79-81]. From epidemiological studies it is clear that vitamin D deficiency is associated with numerous diseases but it is not totally clear if it is a cause or a effect. Due to disease and medication effects, children with rheumatic diseases have additional needs for vitamin $\mathrm{D}$ supplementation. It is reasonable to assume that a child with a rheumatic disease, especially if treated with steroids, needs at least double the daily recommended dose of vitamin $\mathrm{D}$ for age (approximately $2000 \mathrm{UI} /$ day) [82]. This high dose is needed as immunomodulatory and epigenetic benefits from 1,25(OH)D (hormonal form of vitamin $\mathrm{D}$ ) can be achieved only when high levels are present in the tissues [24]. Vitamin D supplementation is an appealing adjunct treatment option in JIA and other inflammatory rheumatic diseases due to its pleiotropic effects, which may both minimize bone fragility and attenuate the immune hyperactivation. It is clear that it is now of great importance that pediatric rheumatologists use vitamin D supplementation for children with rheumatic diseases as well as systematically collect data about vitamin D and disease severity and outcome that will inform Vitamin D guidelines in the future.

\section{Competing interests}

The authors declare that they have no competing interests.

\section{Authors' contributions}

Both authors have made substantive intellectual contributions to the manuscript. Both authors read and approved the final manuscript.

\section{Author details}

${ }^{1}$ Clinic of Pediatrics, Clinical Center, Faculty of Medicine, University of Nis, Bul dr Zorana Djindjica 48, 18000 Nis, Serbia. ${ }^{2}$ Dipartimento di Neuroscienze, Area del Farmaco e Salute del Bambino (NEUROFARBA), Viale Pieraccini, 24, 50139 Firenze, Italy.

Received: 22 December 2014 Accepted: 22 May 2015 Published online: 29 May 2015

\section{References}

1. All Nobel Prizes in Physiology or Medicine - Nobelprize.org [http:// www.nobelprize.org/nobel_prizes/medicine/laureates/].
2. Casimir Funk. The etiology of the deficiency diseases. Beri-beri, polyneuritis in birds, epidemic dropsy, scurvy, experimental scurvy in animals, infantile scurvy, ship beri-beri, pellagra. J State Med. 1912; 20:341-68.

3. Cutolo M, Pizzorni C, Sulli A. Vitamin D endocrine system involvement in autoimmune rheumatic diseases. Autoimmun Rev. 2011;11:84-7.

4. Hammes SR. The further redefining of steroid-mediated signaling. Proc Natl Acad Sci USA. 2003;100(5):21680-2170.

5. Haussler MR et al. The nuclear vitamin D receptor controls the expression of genes encoding factors which feed the "Fountain of Youth" to mediate healthful aging. J Steroid Biochem Mol Biol. 2010;121:88-97.

6. Arnson Y, Amital H, Shoenfeld Y. Vitamin D and autoimmunity new etiological and therapeutical considerations. Ann Rheum Dis. 2007;66:1137-42.

7. De Luca H. Overview of general physiologic features and functions of vitamin D. Am J Clin Nutr. 2004;80:1689S-96.

8. Vojinovic J. Vitamin D, receptor agonists' anti-inflammatory properties. Ann N Y Acad Sci. 2014;1317:47-56.

9. Arkema EV, Hart JE, Bertrand KA, Laden F, Grodstein F, Rosner BA, Karlson EW, Costenbader $\mathrm{KH}$. Exposure to Ultraviolet-B and risk of developing rheumatoid arthritis among women in the Nurses' Health Study. Ann Rheum Dis. 2013;72:506-11.

10. Nisar MK, Masood F, Cookson P, Sansome A, Östörhave AJK. What do we know about juvenile idiopathic arthritis and vitamin D? A systematic literature review and meta-analysis of current evidence. Clin Rheumatol. 2013;32(6):729-34

11. Robinson AB, Tangpricha V, Yow E, Gurion R, Schanberg LE, McComsey GA APPLE Investigators. Vitamin D deficiency is common and associated with increased C-reactive protein in children and young adults with lupus: an Atherosclerosis Prevention in Pediatric Lupus Erythematosus substudy. Lupus Sci Med. 2014;1(1):e000011. doi:10.1136/lupus-2014-000011.

12. Holick MF. The D-lightful vitamin D for child health. J Parent Enter Nutr. 2012;36 Suppl 1:9S-19.

13. De Luca HF. Vitamin D: the vitamin and the hormone. Fed Proc. 1974;33:2211-9.

14. Cheng JB, Levine MA, Bell NH, Mangelsdorf DJ, Russell DW. Genetic evidence that the human CYP2R1 enzyme is a key vitamin D 25hydroxylase. Proc Natl Acad Sci USA. 2004;101:7711-5.

15. Holick MF. Vitamin D, deficiency. N Engl J Med. 2007;357:266-81

16. Rosen JC. Vitamin D, insufficiency. NEJM. 2011;364:248-54.

17. Jurutka PW, Bartik L, Whitfield GK, Mathern DR, Barthel TK, Gurevich M, Hsieh JC, Kaczmarska M, Haussler CA, Haussler MR. Vitamin D receptor: key roles in bone mineral pathophysiology, molecular mechanism of action, and novel nutritional ligands. J Bone Miner Res. 2007;22:V2-10.

18. Adams JS, Hewison M. Update in vitamin D. J Clin Endocrinol Metab. 2010;95(2):471-8.

19. Mora R, Iwata M, von Andrian UH. Vitamin effects on the immune system: vitamins A and D take center stage. Nat Rev Immunol. 2008;8:685-98.

20. Carlberg C, Campbell JM. Vitamin D receptor signaling mechanisms: Integrated actions of a well-defined transcription factor. Steroids. 2013;78:127-36.

21. Norman AW. Vitamin D, receptor: New assignments for an already busy receptor. Endocrinology. 2006;147:5542-8.

22. Carlberg C, Molnár F. Current status of vitamin D signaling and its therapeutic applications. Curr Top Med Chem. 2012;12:1-20.

23. Huhtakangas JA, Olivera CJ, Bishop JE, Zanello LP, Norman AW. The vitamin D receptor is present in caveolae enriched plasma membranes and binds 1a,25(OH)2-vitamin D3 in vivo and in vitro. Mol Endocrinol. 2004;18:2660-71.

24. Cutolo M, Paolino S, Sulli A, Smith V, Pizzorni C, Seriolo B. Vitamin D, steroid hormones, and autoimmunity. Ann N Y Acad Sci. 2014;1317:39-46.

25. Sundar KS, Rahman I. Vitamin D and susceptibility of chronic lung diseases; role of epigenetics. Frontiers in Pharmacology. 2011;2(50):1-10.

26. Haussler MR, Whitfield GK, Kaneko I, Haussler CA, Hsieh D, Hsieh JC, Jurutka PW. Molecular mechanisms of vitamin D action. Calcif Tissue Int. 2013;92(2):77-98

27. Margolis RN, Christakos S. The nuclear receptor superfamily of steroid hormones and vitamin D gene regulation. Ann N Y Acad Sci. 2010;1192:208-14.

28. Prue HH, Shelley G, Finlay-Jones JJ. Modulation of the immune system by UV radiation: more than just the effects of vitamin D? Nature Rev. 2011:11:584-96.

29. Adams JS, Hewison M. Unexpected actions of vitamin D: new perspectives on the regulation of innate and adaptive immunity. Nat Clin Pract Endocrinol Metab. 2008;4:80-90.

30. Liu PT, Stenger S, Li H, Wenzel L, Tan BH, Krutzik SR, Ochoa MT, Schauber J, Wu K, Meinken C, Kamen DL, Wagner M, Bals R, Steinmeyer A, Zügel U, 
Gallo RL, Eisenberg D, Hewison M, Hollis BW, Adams JS, Bloom BR, Modlin RL. Toll-like receptor triggering of a vitamin D-mediated human antimicrobial response. Science. 2006;311:1770-3.

31. Adorini L, Penna G. Control of autoimmune diseases by the vitamin D endocrine system. Nature Clin Pract Rheumatol. 2008;4:404-12.

32. Colin EM, Asmawidjaja PS, van Hamburg JP, Mus AM, van Driel M, Hazes JM, van Leeuwen JP, Lubberts E. 1,25-dihydroxyvitamin D3 modulates Th17 polarization and interleukin-22 expression by memory T cells from patients with early rheumatoid arthritis. Arthritis Rheum. 2010;62:132-42.

33. Di Rosa M, Malaguarnera M, Nicoletti F, Malaguarnera L. Vitamin D3. a helpful immuno-modulator. Immunology. 2011;134(2):123-39. doi:10.1111/j.1365-2567.2011.03482.x.

34. Cutolo M, Plebani M, Shoenfeld Y, Adorini L, Tincani A. Vitamin D endocrine system and the immune response in rheumatic diseases. Vitam Horm. 2011;86:327-51.

35. Prietl B, Treiber G, Pieber TR, Amrein K. Vitamin $D$ and immune function. Nutrients. 2013;5(7):2502-21.

36. Cantorna MT, Mahon BD. Mounting evidence for vitamin D as an environmental factor affecting autoimmune disease prevalence. Exp Biol Med (Maywood). 2004;229:1136-42.

37. Haque UJ, Bartlett SJ. Relationships among vitamin D, disease activity, pain and disability in rheumatoid arthritis. Clin Exp Rheumatol. 2010;28:745-7.

38. Mauf S, Penna-Martinez M, Jentzsch T, Ackermann H, Henrich D, Radeke HH, Brück P. Immunomodulatory effects of 25-hydroxyvitamin D3 on monocytic cell differentiation and influence of vitamin D3 polymorphisms in type 1 diabetes. J Steroid Biochem Mol Biol. 2015;147:17-23.

39. Reis JP, von Mühlen D, Miller 3rd ER, Michos ED, Appel LJ. Vitamin D status and cardiometabolic risk factors in the United States adolescent population. Pediatrics. 2009;124(3):e371-9.

40. Mohr S, Garland C, Gorham E, Garland F. The association between ultraviolet B irradiance, vitamin $D$ status and incidence rates of type 1 diabetes in 51 regions worldwide. Diabetologia. 2008:51:1391-8.

41. Munger KL, Levin LI, Hollis BW, Howard NS, Ascherio A. Serum 25-hydroxyvitamin D levels and risk of multiple sclerosis. JAMA. 2006:296:2832-8.

42. Cimaz R, Stagi S. Managing pediatric osteoporosis. Int J Clin Rheumatol. 2013;8(5):1-4.

43. Canalis E, Mazziotti G, Giustina A, Bilezikian JP. Glucocorticoidinduced osteoporosis: pathophysiology and therapy. Osteoporos Int. 2007;18:1319-28.

44. von Scheven E, Corbin KJ, Stagi S, Cimaz R. Glucocorticoid-associated osteoporosis in chronic inflammatory diseases: epidemiology, mechanisms, diagnosis, and treatment. Curr Osteoporos Rep. 2014;12(3):289-99.

45. Rodd C, Lang B, Ramsay T, Alos N, Huber AM, Cabral DA, Scuccimarri R, Miettunen PM, Roth J, Atkinson SA, Couch R, Cummings EA, Dent PB, Ellsworth J, Hay J, Houghton K, Jurencak R, Larché M, LeBlanc C, Oen K, Saint-Cyr C, Stein R, Stephure D, Taback S, Lentle B, Matzinger M, Shenouda N, Moher D, Rauch F, Siminoski K, Ward LM; Canadian Steroid-Associated Osteoporosis in the Pediatric Population (STOPP) Consortium. Incident vertebral fractures among children with rheumatic disorders 12 months after glucocorticoid initiation: a national observational study. Arthritis Care Res (Hoboken). 2012;64(1):122-31.

46. Heaney RP. The vitamin D requirement in health and disease. J Steroid Biochem Mol Biol. 2005;97:13-9.

47. Looker AC, Johnson CL, Lachner DA, Pfeiffer CM, Schleicher RL, Sempos CT. Vitamin D status: United States, 2001-2006. NCHS Data Brief. 2011;59:1-8.

48. Reed A, Haugen M, Pachman LM, Langman CB. Abnormalities in serum osteocalcin values in children with chronic rheumatic diseases. J Pediatr. 1990;116(4):574-80.

49. Reed A, Haugen M, Pachman LM, Langman CB. 25-Hydroxyvitamin D therapy in children with active juvenile rheumatoid arthritis: short-term effects on serum osteocalcin levels and bone mineral density. J Pediatr. 1991;1 19:657-60.

50. Pelajo CF, Lopez-Benitez JM, Miller LC. 25-hydroxyvitamin D levels and vitamin $\mathrm{D}$ deficiency in children with rheumatologic disorders and controls. J Rheumatol. 2011;38:2000-4.

51. Soybilgic A, Tesher M, Wagner-Weiner L, Onel KB. A survey of steroidrelated osteoporosis diagnosis, prevention and treatment practices of pediatric rheumatologists in North America. Pediatr Rheumatol Online J. 2014;12:24.

52. Holick MF, Binkley CN, Bischoff-Ferrari AH, Gordon MC, Hanley AD, Heaney $\mathrm{PR}$, Murad MH, Weaver CM. Evaluation, treatment, and prevention of vitamin D deficiency: an endocrine society clinical practice guideline. J Clin Endocrinol Metab. 2011;96(7):1911-30.
53. Ellis JA, Munro JE, Ponsonby AL. Possible environmental determinants of juvenile idiopathic arthritis. Rheumatology (Oxford). 2010;49(3):411-25.

54. Hypponen E, Laara E, Reunanen A, Jarvelin MR, Virtanen SM. Intake of vitamin D and risk of type 1diabetes: a birth-cohort study. Lancet. 2001:358:1500-3.

55. Merlino LA, Curtis J, Mikuls TR, et al. Vitamin D intake is inversely associated with rheumatoid arthritis: results from the lowa Women's Health Study. Arthritis Rheum. 2004;50:72-7.

56. Pelajo CF, Lopez-Benitez JM, Kent DM, Price LL, Miller LC, Dawson-Hughes B. 25-hydroxyvitamin $D$ levels and juvenile idiopathic arthritis: is there an association with disease activity? Rheumatol Int. 2012;32(12):3923-9.

57. Stagi S, Bertini F, Cavalli L, Matucci-Cerinic M, Brandi ML, Falcini F. Determinants of vitamin D levels in children, adolescents, and young adults with juvenile idiopathic arthritis. J Rheumatol. 2014;41(9):1884-92.

58. Hillman LS, Cassidy JT, Chanetsa F, Hewett JE, Higgins BJ, Robertson JD. Percent true calcium absorption, mineral metabolism, and bone mass in children with arthritis: effect of supplementation with vitamin D3 and calcium. Arthritis Rheum. 2008;58(10):3255-63.

59. Carrasco R, Lovell DJ, Giannini EH, Henderson CJ, Huang B, Kramer S, Ranz J, Heubi J, Glass D. Biochemical markers of bone turnover associated with calcium supplementation in children with juvenile rheumatoid arthritis: results of a double-blind, placebo controlled intervention trial. Arthritis Rheum. 2008;58:3932-40.

60. Casella CB, Seguro LPC, Takayama L, Medeiros D, Bonfa E, Pereira RMR Juvenile onset systemic lupus erythematosus: a possible role for vitamin D in disease status and bone health. Lupus. 2012;21:1335-42.

61. Stagi S, Cavalli L, Bertini F, Signorini C, Matucci Cerinic M, de Martino M, Brandi ML, Falcini F. Vitamin D levels in children, adolescents, and young adults with juvenile-onset systemic lupus erythematosus: a cross-sectional study. Lupus. 2014;23:1059-65.

62. Khamiseh G, Vaziri ND, Oveisi F, Ahmadnia MR, Ahmadnia L. Vitamin D absorption, plasma concentration and urinary excretion of $25-$ hydroxyvitamin D in nephrotic syndrome. Proc Soc Exp Biol Med. 1991;196:210-3.

63. Robinson AB, Rabinovich CE. Hypovitaminosis D is prevalent despite vitamin D supplementation in pediatric systemic lupus erythematosus. Abstract in: 72nd Annual Meeting ofthe American College of Rheumatology; 2008; San Francisco, CA.

64. Robinson AB, Thierry-Palmer M, Gibson KL, Rabinovich CE. Disease activity, proteinuria, and vitamin D status in children with systemic lupus erythematosus and juvenile dermatomyositis. J Pediatr. 2012;160(2):297-302

65. Robinson AB, Tangpricha V, Yow E, Gurion R, Schanberg LE, McComsey GA, APPLE Investigators. Vitamin D status is a determinant of atorvastatin effect on carotid intima medial thickening progression rate in children with lupus: an Atherosclerosis Prevention in Pediatric Lupus Erythematosus (APPLE) substudy. Lupus Sci Med. 2014;1 (1):e000037.

66. Azali P, Barbasso Helmers S, Kockum I, Olsson T, Alfredsson L, Charles PJ, Piehl Aulin K, Lundberg IE. Low serum levels of vitamin D in idiopathic inflammatory myopathies. Ann Rheum Dis. 2013;72(4):512-6.

67. Berlanga-Taylor AJ, Knight JC. An integrated approach to defining genetic and environmental determinants for major clinical outcomes involving vitamin D. Mol Diagn Ther. 2014;18(3):261-72.

68. Suaini NH, Koplin JJ, Ellis JA, Peters RL, Ponsonby AL, Dharmage SC, Matheson MC, Wake M, Panjari M, Tan HT, Martin PE, Pezic A, Lowe AJ, Martino D, Gurrin LC, Vuillermin PJ, Tang ML, Allen KJ, HealthNuts Study Investigators. Environmental and genetic determinants of vitamin D insufficiency in 12-month-old infants. J Steroid Biochem Mol Biol. 2014;144 (Pt B):445-54

69. Ellis JA, Scurrah KJ, Li YR, Ponsonby AL, Chavez RA, Pezic A, Dwyer T, Akikusa JD, Allen RC, Becker ML, Thompson SD, Lie BA, Flatø B, Førre O, Punaro M, Wise C, Finkel TH, Hakonarson H, Munro JE. Epistasis amongst PTPN2 and genes of the vitamin D pathway contributes to risk of juvenile idiopathic arthritis. J Steroid Biochem Mol Biol. 2015;145:113-20.

70. Mosaad YM, Hammad EM, Fawzy Z, Abdal Aal IA, Youssef HM, ElSaid TO, Monir R, El-Deek BS. Vitamin D receptor gene polymorphism as possible risk factor in rheumatoid arthritis and rheumatoid related osteoporosis. Hum Immunol. 2014;75(5):452-61.

71. Vojinovic J, Jeftovic T, Lazaraevic D, Susic G. Long term outcome and fokl VDR polimorphism in JIA patients on anti-TNF treatment [abstract]. Ann Rheum Dis. 2013;72(Suppl3):739.

72. Institute of Medicine (IOM). Dietary Reference Intakes for Calcium and Vitamin D. Committee to Review Dietary Reference Intakes for Calcium and 
Vitamin D. Washington DC: National Academies Press 2011. Available at http://iom.edu/ /media/Files/Report\%20Files/2010/Dietary-ReferenceIntakes-for-Calcium-and-Vitamin-D/

Vitamin\%20D\%20and\%20Calcium\%202010\%20Report\%20Brief.pdf.

73. Heaney RP. Human serum 25-hydroxycholecalciferol response to extended oral dosing with cholecalciferol. Am J Clin Nutr. 2003;77(1):204-10

74. Gordon CM, Williams AL, Feldman HA, May J, Sinclair L, Vasquez A, Cox JE. Treatment of Hypovitaminosis D in Infants and Toddlers. The Journal of Clinical Endocrinology and Metabolism 2008, 93(7): 2716-2721.

75. Armas LA, Hollis BW, Heaney RP. Vitamin D2 is much less effective than vitamin D3 in humans. J Clin Endocrinol Metab. 2004;89(11):5387-91.

76. Hossein-Nezhad A, Holick MF. Optimize dietary intake of vitamin D: an epigenetic perspective. Curr Opin Clin Nutr Metab Care. 2012;15(6):567-79.

77. Sundar IK, Rahman I. Vitamin D and susceptibility of chronic lung disease: role of epigenetics. Front Pharamacol. 2011;2(50):1-10.

78. Andjelkovic Z, Vojinovic J, Pejnovic N, Popovic M, Dujic A, Mitrovic D, Pavlica L, Stefanovic D. Disease modifynig and immunoregulatory effects of high oral dose $1 \mathrm{a}(\mathrm{OH}) \mathrm{D} 3$ in rheumatoid arthritis patients. Clin Exp Rheumatol. 1999;17:59-62.

79. Wahl DA, Cooper C, Ebeling PR, Eggersdorfer M, Hilger J, Hoffmann K, Josse R, Kanis JA, Mithal A, Pierroz DD, Stenmark J, Stöcklin E, Dawson-Hughes B. A global representation of vitamin D status in healthy populations. Arch Osteoporos. 2012;7(1-2):155-72.

80. Bjelakovic G, Gluud LL, Nikolova D, Whitfield K, Wetterslev J, Simonetti RG, Bjelakovic M, Gluud C. Vitamin D supplementation for prevention of mortality in adults. Cochrane Database Syst Rev. 2014;1:CD007470.

81. Hossein-Nezhad A, Spira A, Holick MF. Influence of vitamin D status and vitamin D3 supplementation on genome wide expression of white blood cells: a randomized double-blind clinical trial. PLoS One. 2013;8(3), e58725. doi:10.1371/journal.pone.0058725.

82. von Scheven E, Burnham JM. Vitamin D Supplementation in the Pediatric Rheumatology Clinic. Curr Rheumatol Rep. 2011;13:110-6.

\section{Submit your next manuscript to BioMed Central and take full advantage of:}

- Convenient online submission

- Thorough peer review

- No space constraints or color figure charges

- Immediate publication on acceptance

- Inclusion in PubMed, CAS, Scopus and Google Scholar

- Research which is freely available for redistribution 